\title{
First record of the genus Genaemirum (Hymenoptera, Ichneumonidae, Ichneumoninae) from West Africa, with the description of a new species from Guinea
}

\author{
Davide DAL POS ${ }^{1, *} \&$ Pascal ROUSSE ${ }^{2}$ \\ ${ }^{1}$ Department of Biology, University of Central Florida, 4110 Libra Dr. Rm 442, \\ Orlando, FL 32816, USA. \\ ${ }^{1}$ C/o Museo di Storia Naturale di Venezia, Santa Croce 1730, 30135 Venice, Italy. \\ ${ }^{2}$ Muséum national d'Histoire naturelle, 45 rue Buffon, 75005 Paris, France. \\ ${ }^{*}$ Corresponding author: daveliga@gmail.com \\ ${ }^{2}$ Email: rousse.pascal@wanadoo.fr \\ ${ }^{1}$ urn:1sid:zoobank.org:author:0965BE77-B35C-4641-9C38-A83B8582FE37 \\ ${ }^{2}$ urn:1sid:zoobank.org:author:B06C2640-700A-429B-AA2F-1BE09251C845
}

\begin{abstract}
A new species of the Afrotropical genus Genaemirum Heinrich, 1936 is described from a single female specimen from Guinea and compared to the closest species, G. rhinoceros Heinrich, 1967. Genaemirum filipazzii sp. nov. also provides the first record of the genus for West Africa. An updated key to the species is included.
\end{abstract}

Keywords. Ichneumonidae, Ichneumoninae, Genaemirum, Guinea, new species, new record.

Dal Pos D. \& Rousse P. 2018. First record of the genus Genaemirum (Hymenoptera, Ichneumonidae, Ichneumoninae) from West Africa, with the description of a new species from Guinea. European Journal of Taxonomy 473: 1-11. https://doi.org/10.5852/ejt.2018.473

\section{Introduction}

Genaemirum Heinrich, 1936 is an endemic Afrotropical genus with eight recognized species up to now (Rousse et al. 2016), and with a scattered distribution between Southern and Eastern Africa (Table 1). The suprageneric placement of Gemaemirum is far from clear. Heinrich (1967) placed the genus within the tribe Heresiarchini (= Protichneumonini sensu Heinrich) and the newly described subtribe Apatetorina, but according to the cladistic analysis of Sime \& Wahl (2002), Heresiarchini are paraphyletic. Despite this recent finding, Tereshkin (2009) maintained the traditional concept of Heresiarchini and therefore the position of Genaemirum. In a later paper, Rousse et al. (2016) did not speculate about the position of the genus, but agreed upon the fact that "the gradual curve of the propodeum in profile is typical of the tribe Heresiarchini".

Genaemirum can be distinguished from the other genera by the combination of the following characters: the flattened and uncarinate scutellum; the long and evenly curved propodeum with area superomedia and 
area basalis fused into a long and smooth mid-longitudinal surface; highly specialized head structures, such as appendages of the apex of the gena and / or horn-like projections or carinae on the frons, behind the antennal sockets (Heinrich 1936, 1967; Rousse et al. 2016).

The biology of the genus is poorly known. According to Rousse et al. (2016), species of Genaemirum are likely to be idiobiont parasitoids of pupae of Lepidoptera, as suggested by both indirect observations (such as an oxypygous metasoma and the biology of the species belonging to many heresiarchines, such as Coelichneumon Thomson, 1893), and direct rearing of G. phagocossorum (Rousse, Broad \& van Noort, 2016), which has been reported to emerge from logs of Eucalyptus nitens (H. Deane \& Maiden) (Myrtales: Myrtaceae) heavily infested by Coryphodema tristis (Drury, 1782) (Lepidoptera: Cossidae). The particular appendages and modifications of the head are not clearly understood. Heinrich (1967) speculated they could be an adaptation either to access the host or emerge from a particular substrate. As they are apparently restricted to females, Rousse et al. (2016) furthermore suggested they could be involved in host foraging, for example by facilitating the progression of the female within the frass-filled feeding tunnels of the host caterpillars.

The present publication describes a new species of Genaemirum collected from Guinea, expanding the distribution of the genus to the Western Africa. An updated key to the species of Genaemirum is also provided.

\section{Material and methods}

\section{Photographs}

A dissecting stereo microscope (OPTIKA SZM-2) was used for observation and study. Photographs were taken with a Canon Eos 600D, lens Canon MP-E $65 \mathrm{~mm} \mathrm{f} / 2.8$ 1-5 $\times$ Macro and Sigma $105 \mathrm{~mm}$ f/2.8 Macro DG OS HSM, using Combine ZP for the stacking (Hadley 2008).

\section{Mapmaking}

The records are in decimal degree (datum WGS84) and distribution maps were produced using QGIS 2.14.22 with shape files produced by Natural Earth (http://www.naturalearthdata.com) and Map Library (http://www.maplibrary.org).

\section{Depositories and abbreviations}

NHMD $=$ Statens Naturhistoriske Museum, University of Copenhagen, Denmark (Lars Vilhelmsen)

$\mathrm{POL}=$ Post-ocellar line index

$\mathrm{OOL}=$ Oculo-ocellar line index

ZSMC = Zoologische Staatssammlung, Munich, Germany (Stefan Schmidt)

\section{Comparative specimen}

The holotype of the new species was compared with the female holotype of Genaemirum rhinoceros Heinrich, 1967 (ZSMC: Type-No: ZSM-HYM-00254) collected in Uganda. For major details on the labels refer to Rousse et al. (2016). 


\title{
Results
}

\section{Taxonomy}

\author{
Class Hexapoda Blainville, 1816 \\ Order Hymenoptera Linnaeus, 1758 \\ Superfamily Ichneumonoidea Latreille, 1802 \\ Family Ichneumonidae Latreille, 1802 \\ Subfamily Ichneumoninae Latreille, 1802 \\ Tribe Heresiarchini Ashmead, 1900 \\ Genus Genaemirum Heinrich, 1936 \\ Genaemirum filipazzii sp. nov. \\ urn:lsid:zoobank.org:act:30DC3829-233C-4D2F-978E-E1E443F6A583
}

Figs $1-3,6,8,10-14$

\section{Diagnosis}

Body length $14.5 \mathrm{~mm}$. Head mostly reddish-brown with frons, vertex and occiput black; mesosoma black with isolated reddish-brown markings; metasoma and legs reddish brown but hind coxa partly black; wings hyaline; antenna with 33 flagellomeres; lower gena not produced laterally; clypeus transverse and with the apical margin slightly truncate in the middle; lower frons smooth and short, separated from coarsely rugose upper frons by a transverse M-shaped carina; mesosoma densely to sparsely punctate; metasoma densely punctate on tergites $1-4$, sparsely punctate on the remaining tergites.

\section{Etymology}

The species is dedicated by the first author (DDP) to his friend, Luca Filipazzi (Milano, Italy) and to his courageous battle, always with a smile on his face, against Duchenne muscular dystrophy. As a modest thanksgiving for all these years of friendship and inspiration, his name is now set among Nature's wonders, as a little piece of eternity.

\section{Material examined}

\section{Holotype}

GUINEA: + , "N’Zérékoré [Nzérékoré] / Fr. Guinea / 24/4 1950 / Sv. Herold Olsen" (NHMD). The holotype is in good condition with left wings detached and glued on a label pinned below the specimen, but the apical flagellomeres of the right antenna are missing.

\section{Description}

\section{Female}

HEAD. Mandible rather stout, punctate and setose, slightly concave on outer aspect, teeth blunt with upper tooth about $2.0 \times$ lower tooth; malar space $0.2 \times$ mandible basal width; occipital carina meeting hypostomal carina distant from mandible base by $0.8 \times$ basal width of mandible; hypostomal carina raised, lamelliform; clypeus $3.2 \times$ as wide as medially high, flat, differentiated from face by suture, punctate with apical margin smoother and slightly truncate in middle; face $4.6 \times$ wider than high, matt and densely punctate, with a mid-longitudinal, horn-like, projecting lamella; lower frons smooth and short, separated from upper frons by a transverse M-shaped carina; upper frons and stemmaticum with a differentiated coarsely rugose surface; vertex very faintly coriaceous with inconspicuous dense punctures near occipital carina; temple about as wide as eye, roundly narrowed behind eyes; occipital carina sharp, ventrally lamellate; ocellar triangle wider than long, ocelli rather small, POL 1.1, OOL 1.4; antenna stout, widened medially, thinner apically, with 33 flagellomeres, first flagellomere $1.8 \times$ as long 

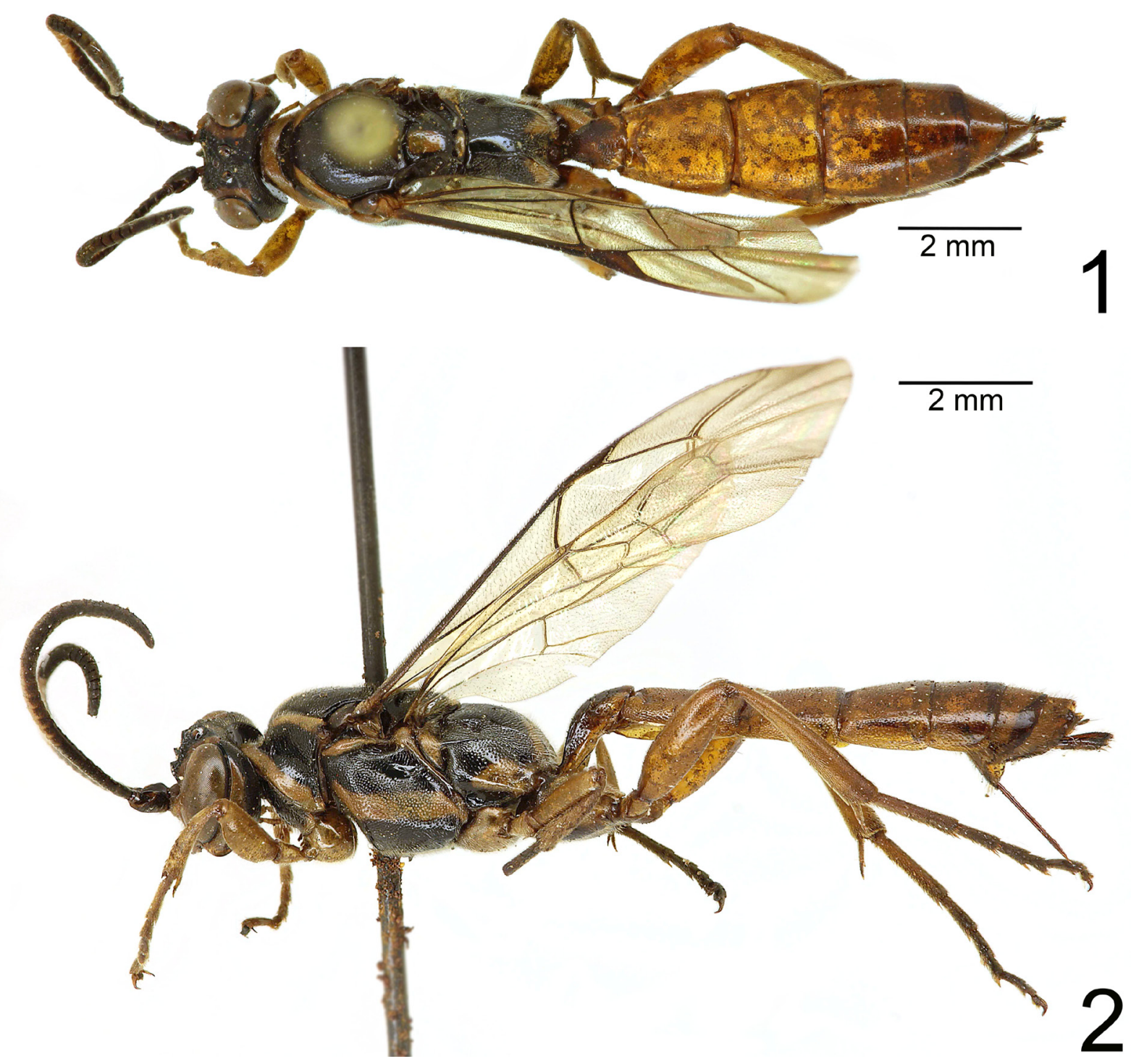

Figs 1-2. Genaemirum filipazzii sp. nov., holotype,, , habitus (NHMD). 1. Dorsal view. 2. Lateral view.
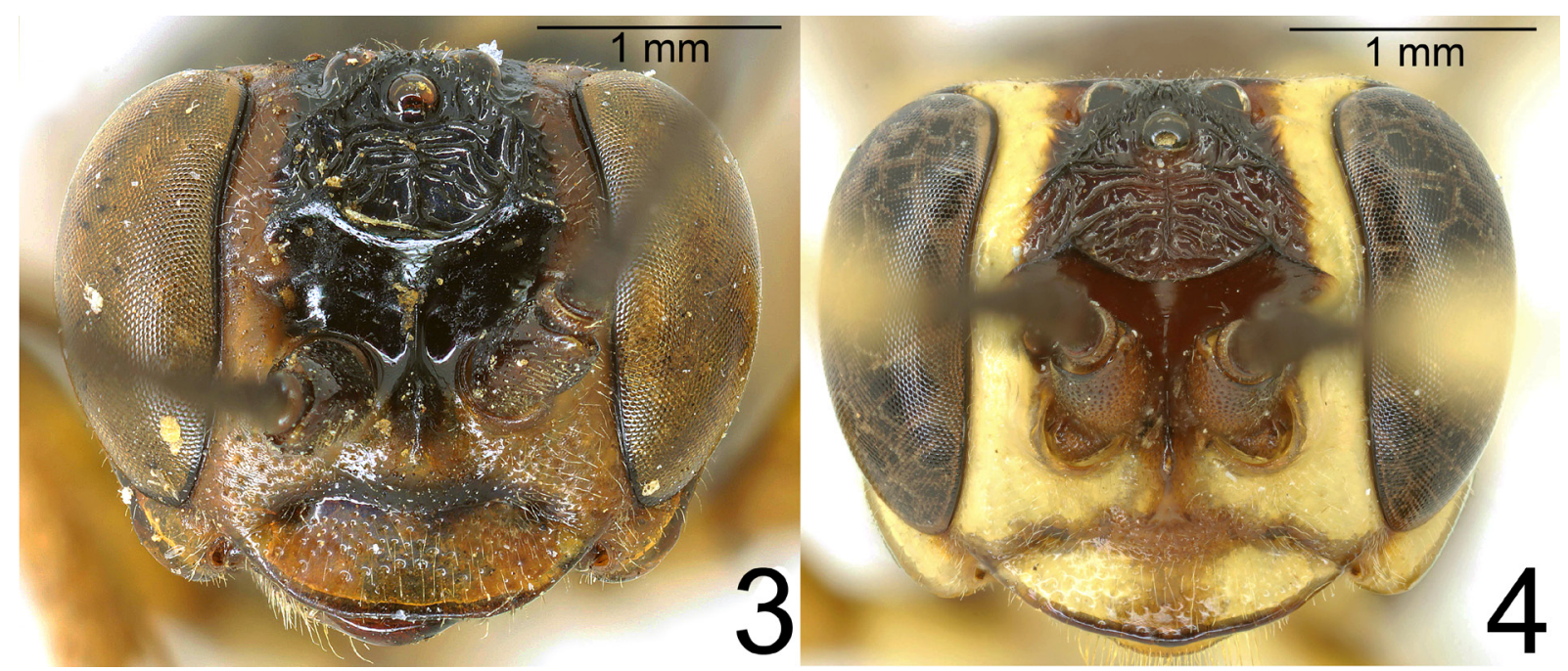

Fig. 3-4. Frontal view of the face. 3. Genaemirum filipazzii sp. nov., holotype,, (NHMD). 4. Genaemirum rhinoceros Heinrich, 1967, holotype, 9 (ZSMC).. 
DAL POS D. \& ROUSSE P., On a new species of Genaemirum (Ichneumoninae) from West Africa
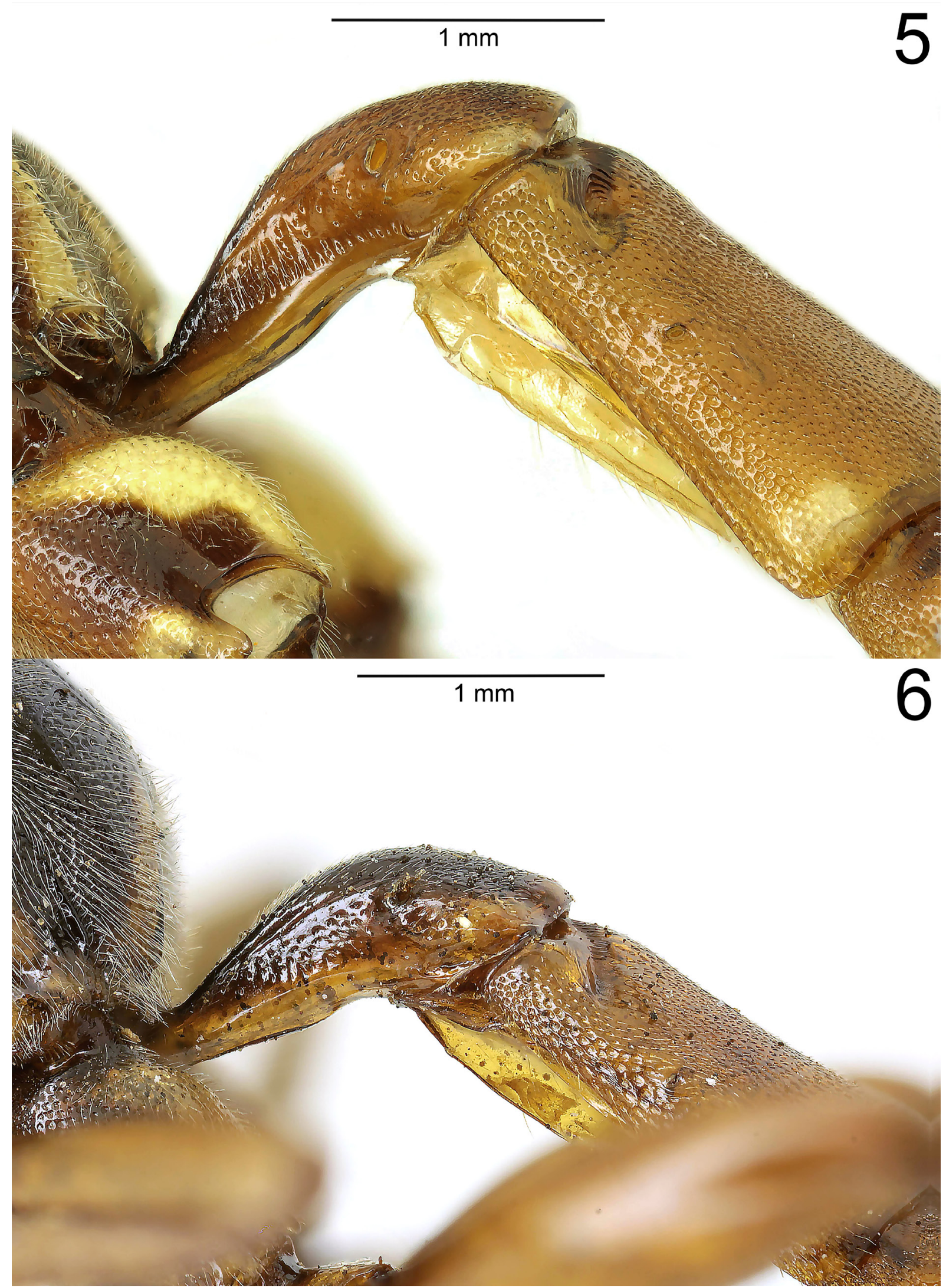

Figs 5-6. Lateral view of the first tergite. 5. Genaemirum rhinoceros Heinrich, 1967. 6. Genaemirum filipazzii sp. nov. 
as apically wide, second $1.3 \times$ as long as wide, then widening towards middle with $8^{\text {th }}$ flagellomere $1.0 \times$ as long as wide.

Mesosoma. Pronotum striate on ventral margin, sparsely punctate centrally, otherwise finely and densely punctate; pronotal collar punctate to puncto-striate, epomia strong; mesopleuron densely punctate, punctures finer on epicnemium and subtegular ridge, speculum smooth and shining, mesopleural groove smooth above speculum, epicnemial carina nearly reaching pronotal margin below expanded subtegular ridge, dorsally fading into punctures; metapleuron densely punctate to nearly smooth ventrally; mesoscutum evenly rounded, finely and densely punctate laterally, sparsely punctate centrally, notaulus distinct to anterior third, scuto-scutellar groove quite smooth; scutellum finely and more sparsely punctate, without lateral carina, quite flat in profile; propodeum typical of genus, gently and evenly rounded in profile with median areas fused, carination distinct but weak, densely punctate with punctation obsolescent in mid-basal area.

LEGS. Fore and mid tibiae with short and rather dense bristles along anterior faces, bristle sockets large and cupular.

WINGS. Areolet closed and rhomboidal.

Metasoma. Tergite 1 densely punctate, rather short and strongly widened from base to spiracle, lateral and submedian dorsal carinae strong; tergites $2-4$ punctate and coriaceous, posteriorly shining, with traces of striation basally, gastrocoelus deep, thyridia separated by $2.1 \times$ their own width; following tergites finely and sparsely punctate, tergites $6-7$ with strong setae; ovipositor sheath slightly protruding beyond metasomal apex.

Colour. Antennae black with a whitish median ring; head mostly reddish-brown with frons, vertex and occiput black; mesosoma black with reddish-brown markings on: dorsal and ventral margins of pronotum, subtegular ridge, centre of mesoscutum, mid-longitudinal band on mesopleuron, scutellum, postero-ventral part of metapleuron, centre of metanotum and posterior corners of propodeum; metasoma uniformly reddish-brown, petiole dorsally darker; legs reddish-brown but hind coxa largely black marked; wings barely infumate, venation testaceous to black.

\section{Male}

Unknown.

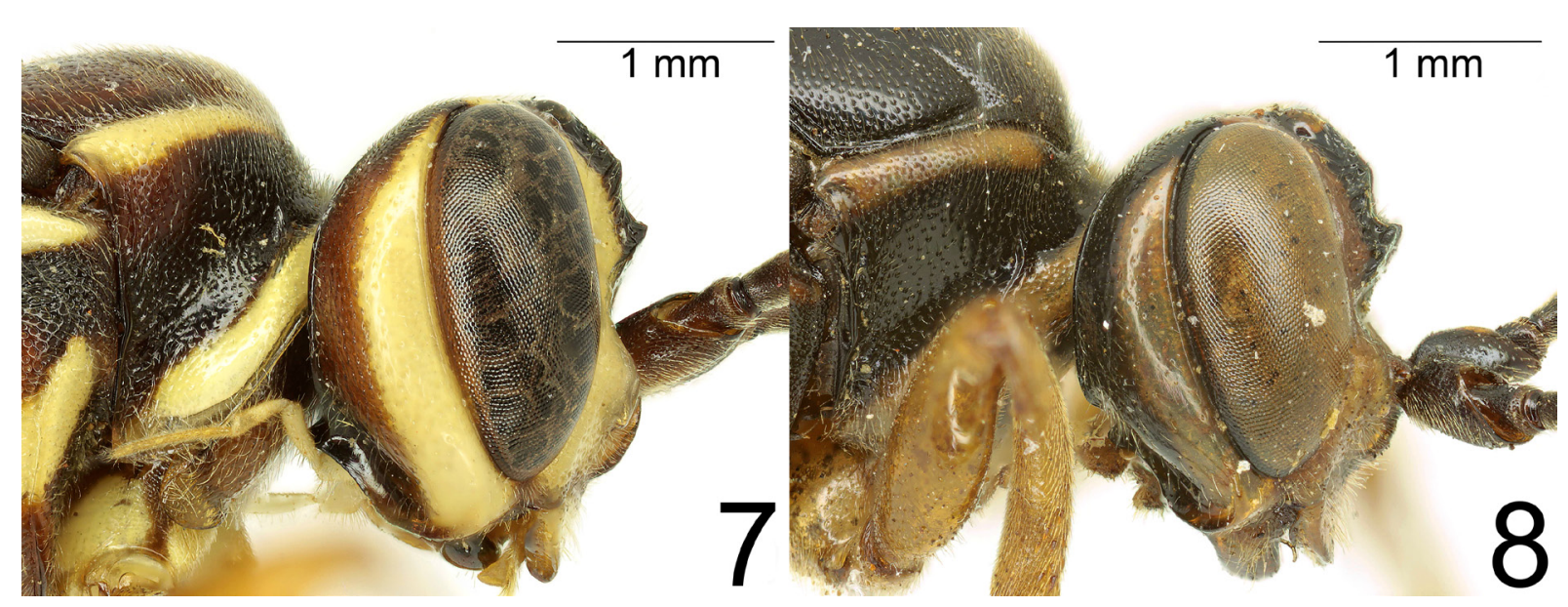

Figs 7-8. Lateral view of the head. 7. Genaemirum rhinoceros Heinrich, 1967. 8. Genaemirum filipazzii sp. nov. 


\section{DAL POS D. \& ROUSSE P., On a new species of Genaemirum (Ichneumoninae) from West Africa}

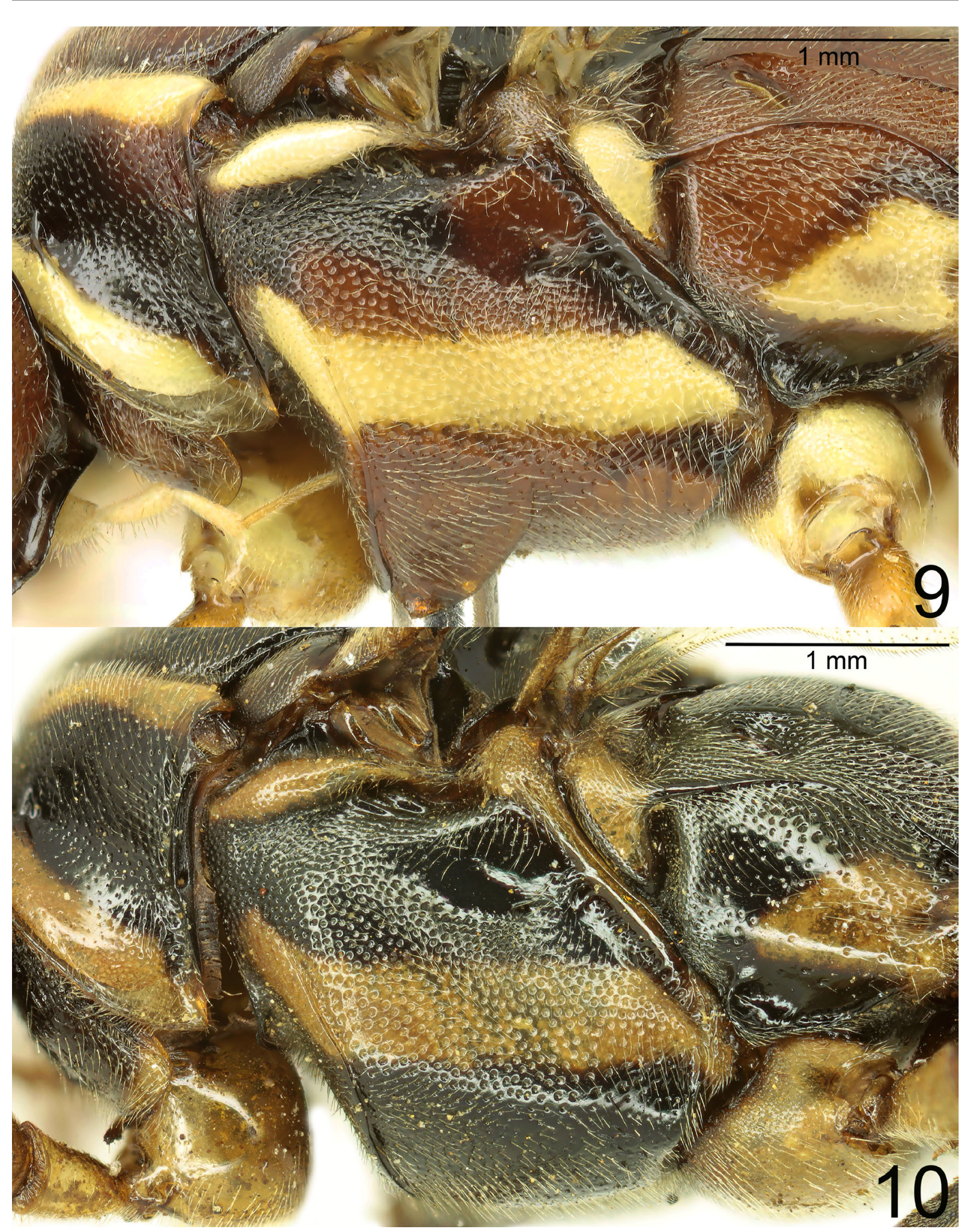

Figs 9-10. Lateral view of mesopleuron. 9. Genaemirum rhinoceros Heinrich, 1967. 10. Genaemirum filipazzii sp. nov. 
Host

Unknown.

\section{Distribution}

Guinea.

\section{Addendum to the key to Genaemirum (after Rousse et al. 2016)}

7. Frons with forked, horn-like projecting carina above antennal scrobes [(A)]; second tergite medially punctate $[(\mathrm{B})]$

- Frons with broad to acute cordate lamella above antennal scrobes [(a)]; second tergite medially longitudinally strigose (metasoma lacking in $\odot$ allotype of G. varianum (Tosquinet, 1896), but $\widehat{\delta}$

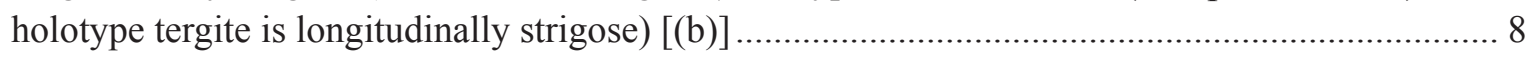

7'. Apical margin of clypeus evenly rounded (Fig. 4); tergite 1 puncto-striate laterally (Fig. 5); ventral part of occipital carina slightly sinuate and not directed inward in lateral view (Fig. 7); head and mesosoma bright red interspersed with numerous large yellow markings (Figs 4, 7, 9); metasoma and legs yellowish-orange with hind coxae largely white (Figs 5, 9); Uganda

G. rhinoceros Heinrich, 1967

- Apical margin of clypeus slightly truncate in the middle (Fig. 3); tergite 1 punctate laterally (Fig. 6); ventral part of occipital carina strongly sinuate and directed inward in lateral view (Fig. 8); head and mesosoma black interspersed with numerous large reddish-brown markings (Figs 1-3, 8, 10-11); metasoma and legs reddish-brown with hind coxa largely black (Figs 6, 12, 14); Guinea

G. filipazzii Dal Pos \& Rousse sp. nov.

\section{Discussion}

The M-shaped carina on the frons easily separates the two closely related species, G. rhinoceros and G. filipazzii sp. nov., from the other species. The newly described species can be differentiated from G. rhinoceros by the slightly truncate apical margin of the clypeus (evenly rounded in G. rhinoceros) and the punctation on the lateral part of tergite 1 (puncto-striate in G. rhinoceros). The overall colouration of the two species is different, although it may have been altered by the preservation condition of the specimens: G. rhinoceros is bright red with yellow markings while the holotype of G. filipazzii sp. nov. is black interspersed with reddish-brown markings. Several other minor differential characters are also worth mentioning: the sculpture on the ventral lobe of the metapleuron (smooth and shining in G. filipazzii sp. nov., striate in $G$. rhinoceros), the different orientation of striation on the pronotum, and the different sculpture of the mesopleural groove (smooth in G. filipazzii sp. nov., punctate in G. rhinoceros).

The new species provides the first record of the genus for Guinea, expanding the distribution of Genaemirum to West Africa (Table 1, Fig. 15). The label lacks detailed collection data so we cannot provide any further biological nor ecological information.

\section{Acknowledgements}

The authors wish to thank Dr Lars Vilhelmsen (NHMD) and Dr Stefan Schmidt (ZSMC) for the loan of the specimens. The first author would also like to personally thank Dr Marco Uliana (Natural History Museum of Venice, Italy) for imaging support, and for considerably improving an early draft of the manuscript. 


\section{DAL POS D. \& ROUSSE P., On a new species of Genaemirum (Ichneumoninae) from West Africa}
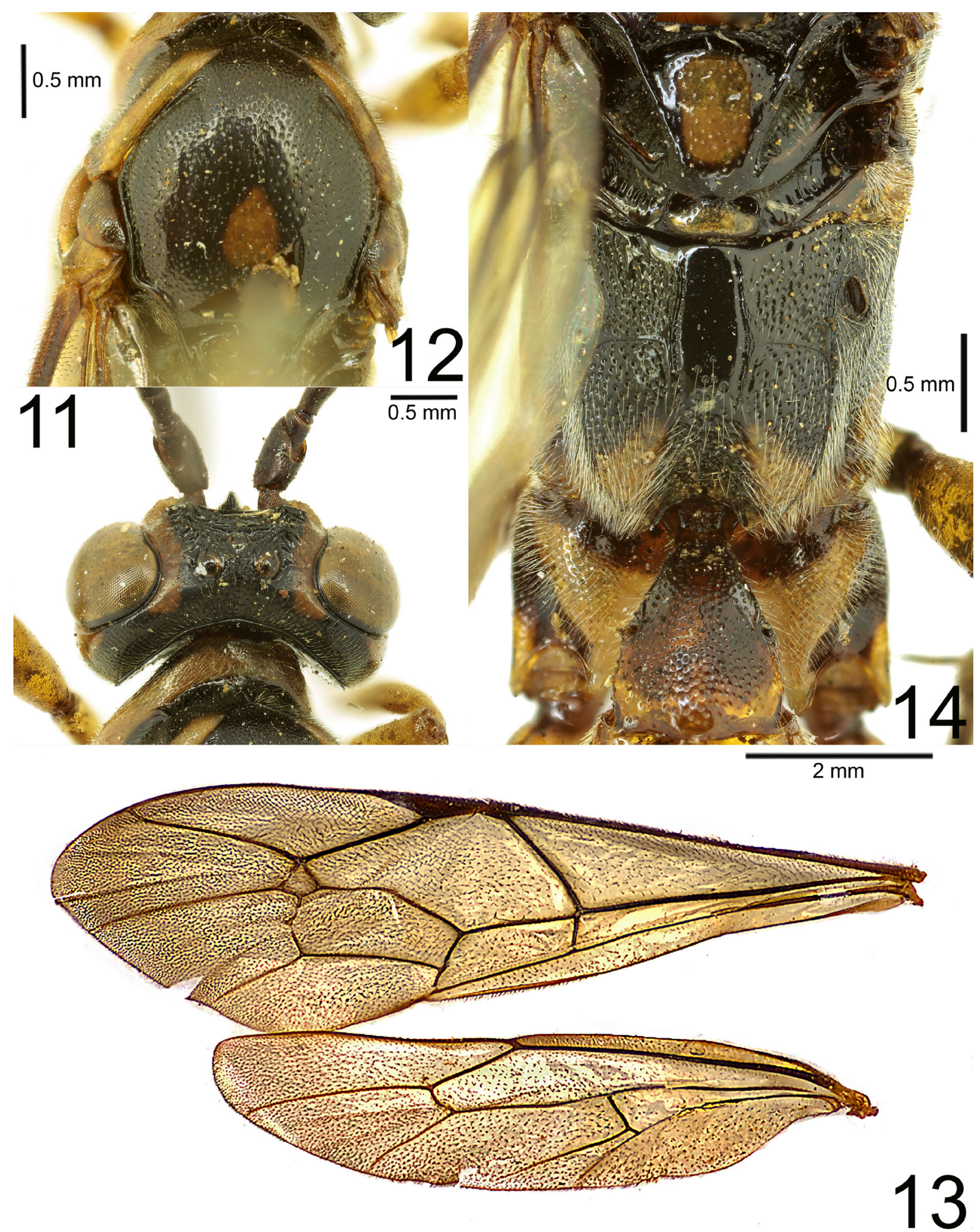

Figs 11-14. Genaemirum filipazzii sp. nov. 11. Head, dorsal view. 12. Mesonotum, dorsal view 13. Fore and hind wings. 14. Propodeum, dorsal view. 
Table 1. Distribution of the genus Genaemirum (Tosquinet 1896; Heinrich 1967; Rousse et al. 2016).

\begin{tabular}{lc}
\hline Species & Known distribution \\
\hline Genaemirum phagocossorum Rousse, Broad \& van Noort, 2016 & \\
Genaemirum fumosum Rousse, Broad \& van Noort, 2016 & South Africa \\
Genaemirum varianum (Tosquinet, 1896) & \\
\hline Genaemirum doryalidis Heinrich, 1967 & Kenya \\
Genaemirum mesoleucum Heinrich, 1936 & Uganda \\
\hline Genaemirum rhinoceros Heinrich, 1967 & Tanzania \\
\hline Genaemirum phacochoerus Rousse, Broad \& van Noort, 2016 & South Africa, Tanzania \\
\hline Genaemirum vulcanicola Heinrich, 1967 & Guinea \\
\hline Genaemirum filipazzii sp. nov. &
\end{tabular}

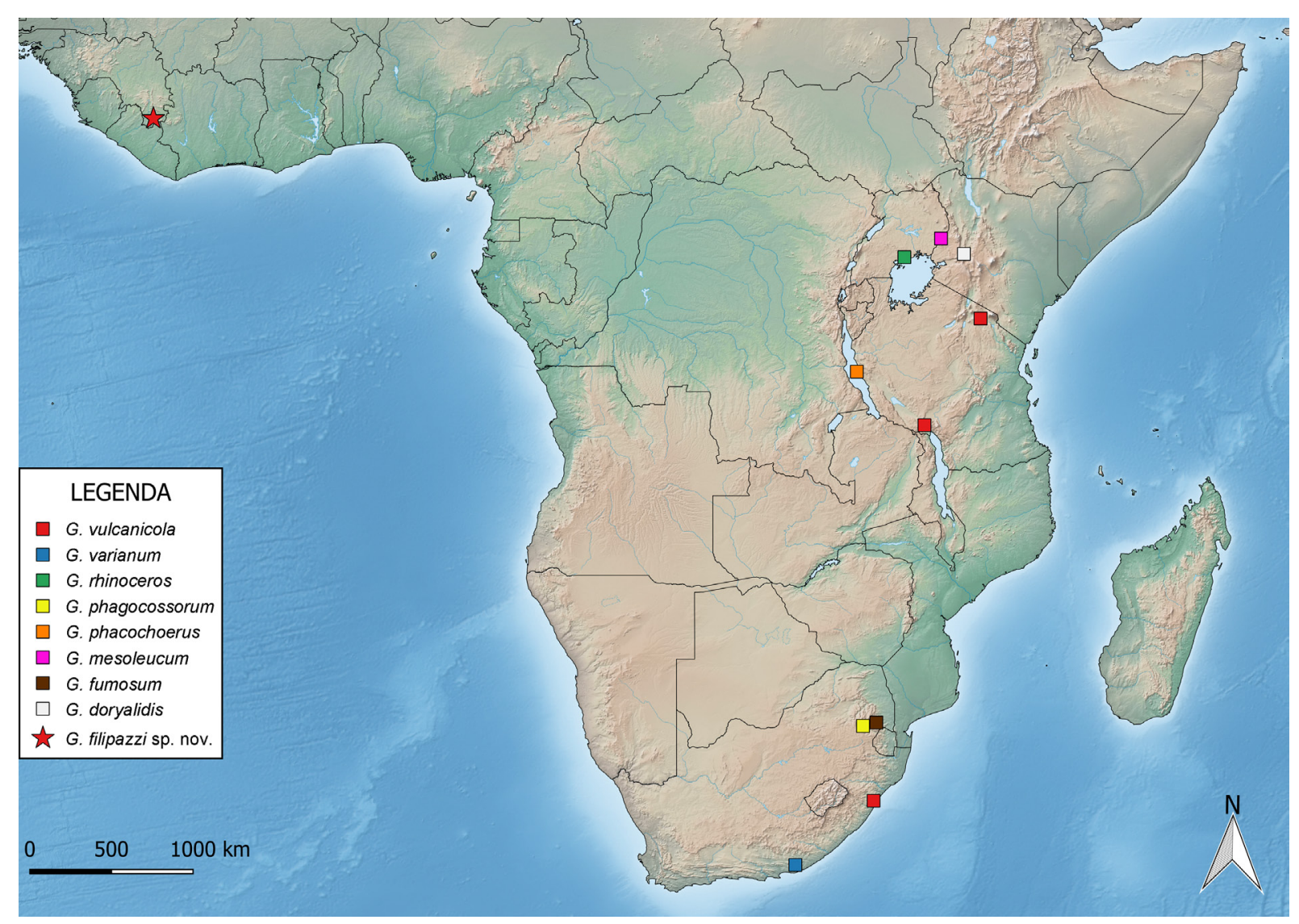

Fig. 15. Distribution of species of Genaemirum Heinrich, 1936: known species (squares) and the new species (star). 
DAL POS D. \& ROUSSE P., On a new species of Genaemirum (Ichneumoninae) from West Africa

\section{References}

Hadley A. 2008. Combine ZM. Available from www.hadleyweb.pwp.blueyonder.co.uk/ [accessed 10 Apr. 2018].

Heinrich G. 1936. Hymenoptera III. Ichneumonidae: Ichneumoninae. Mission scientifique de l'Omo. Mémoires du Muséum national d'Histoire naturelle, Zoologie 3 (28): 227-244.

Heinrich G. 1967. Synopsis and Reclassification of the Ichneumoninae Stenopneusticae of Africa South of Sahara (Hym.). Vol. I. Farmington State College Press, Farmington (NM).

Rousse P., Broad G.R. \& van Noort S. 2016. Review of the genus Genaemirum Heinrich (Hymenoptera, Ichneumonidae, Ichneumoninae) with interactive identification keys to species. ZooKeys 636: 77-105. https://doi.org/10.3897/zookeys.636.10216

Sime K.R. \& Wahl D.B. 2002. The cladistics and biology of the Callajoppa genus-group (Hymenoptera: Ichneumonidae, Ichneumoninae). Zoological Journal of the Linnean Society 134: 1-56. https://doi.org/10.1046/j.1096-3642.2002.00006.x

Tereshkin A.M. 2009. Illustrated key to the tribes of subfamilia Ichneumoninae and genera of the tribe Platylabini of world fauna (Hymenoptera, Ichneumonidae). Linzer biologische Beiträge 41 (2): 13171608.

Tosquinet J. 1896. Contributions à la faune entomologique de l'Afrique. Ichneumonides. Mémoires de la Société entomologique de Belgique 5: 1-430.

Manuscript received: 4 June 2018

Manuscript accepted: 20 August 2018

Published on: 6 November 2018

Topic editor: Gavin Broad

Desk editor: Kristiaan Hoedemakers

Printed versions of all papers are also deposited in the libraries of the institutes that are members of the EJT consortium: Muséum national d'Histoire naturelle, Paris, France; Botanic Garden Meise, Belgium; Royal Museum for Central Africa, Tervuren, Belgium; Natural History Museum, London, United Kingdom; Royal Belgian Institute of Natural Sciences, Brussels, Belgium; Natural History Museum of Denmark, Copenhagen, Denmark; Naturalis Biodiversity Center, Leiden, the Netherlands; Museo Nacional de Ciencias Naturales-CSIC, Madrid, Spain; Real Jardín Botánico de Madrid CSIC, Spain; Zoological Research Museum Alexander Koenig, Bonn, Germany. 